\title{
ANALISIS KEUNTUNGAN USAHA PIA MELATI DI KELURAHAN MARIYAI KABUPATEN SORONG PAPUA BARAT
}

\author{
Doan Irando Fanindi \\ Mex Frans Lodwyk Sondakh \\ Yolanda Pinky Ivanna Rori
}

\begin{abstract}
This study aims to calculate the business profit of "Pia Melati" in Mariyai Village, Sorong Regency, West Papua. This research was conducted for 3 months from September to November 2017. Data collection method used in this study is survey method. Data used is primary data by interviewing techniques to business owners using a questionnaire. Secondary data was obtained from the Food and Industrial Processing Service of Sorong Regency. The results of this study indicate that this business costs for a month is $R p .57,162,654$, revenue is $R p .77,625,000$ and profit is $R p .20,012,346 . R / C$ ratio of 1.35 , is indicated that this business is profitable. *llr+eprm*
\end{abstract}

Keywords: Business profit analysis of "Pia Melati', Mariyai Village, Sorong Regency, West Papua.

\begin{abstract}
ABSTRAK
Penelitian ini bertujuan untuk menghitung keuntungan Usaha "Pia Melati" di Kelurahan Mariyai Kabupaten Sorong Papua Barat. Penelitian ini dilakukan selama 3 bulan dari bulan September hingga November 2017. Metode pengumpulan data yang digunakan adalah metode survei. Data yang di ambil adalah data primer menggunakan teknik wawancara langsung dengan pemilik usaha menggunakan daftar pertanyaan. Data sekunder diperoleh dari Dinas Pengolahan Pangan dan Industri Kabupaten Sorong. Hasil Penelitian menunjukkan biaya dalam produksi sebulan adalah Rp.57.162.654 dan, penerimaan Rp.77.625.000 dan keuntungan Rp.20.012.346. Nilai R/C adalah 1,35 yang berarti usaha ini menguntungkan.*lr+eprm*
\end{abstract}

Kata kunci: analisis keuntungan Usaha "Pia Melati", Kelurahan Mariyai, Kabupaten Sorong, Papua Barat.

\section{PENDAHULUAN}

\section{Latar Belakang}

Pertanian yang merupakan sektor primer dalam suatu perekonomian, pengembangan dan pembangunanya harus dilakukan secara matang sejalan dengan pengembangan sektor industri dan jasa yang menjadi pendukung sehingga tidak terjadi kepincangan dalam perekonomian. Sektor pertanian yang handal merupakan syarat bagi pengembangan sektor industri dan jasa. Pengembangan usaha disektor pertanian dan industri perlu didorong dan dibina menjadi suatu usaha yang berkembang, sehingga mampu mandiri dan dapat meningkatkan pendapatan masyarakat. Selain itu juga dengan adanya pengembangan usaha dapat memberikan perluasan lapangan kerja serta mampu meningkatkan perannya dalam menyediakan barang dan berbagai komponen untuk memenuhi keperluan masyarakat dan permintaan pasar, dalam upaya memperkokoh perekonomian nasional (Sumampouw, 2015).

Memperoleh keuntungan atau laba merupakan tujuan utama berdirinya suatu usaha. Keuntungan yang diperoleh tidak saja digunakan untuk membiayai operasi perusahaan, tetapi juga digunakan untuk ekspansi perusahaan melalui berbagai kegiatan di masa yang akan datang, kemudian yang lebih penting lagi apabila suatu perusahaan terus-menerus memperoleh keuntungan, ini berarti kelangsungan hidup perusahaan akan terjamin. 
Manajer perusahaan harus dapat membuat perencanaan secara terpadu atas semua aktivitas yang sedang maupun akan dilakukan dalam upaya mencapai keuntungan yang diharapkan. Tetapi dalam praktiknya tidak semua perusahaan yang didirikan memperoleh kuntungan seperti yang diharapkan, bahkan tidak sedikit perusahaan yang mati sebelum berkembang, akibat menderita kerugian secara terus-menerus.

Era globalisasi ini, setiap perusahaan yang ingin bertahan dan berkembang diharapkan tanggap dalam menghadapi semua permasalahan yang timbul saat ini maupun di masa yang akan datang dan dapat melihat peluang serta potensi yang dapat memberikan kontribusi menguntungkan bagi perusahaan. Faktor penyebab kegagalan perusahaan adalah salah dalam membuat atau mengambil keputusan dalam rangka pengelolaan keuangan sehingga kegiatan perusahaan terganggu.

Agar perusahaan tidak menderita kerugian, maka perlu dilakukan perencanaan yang matang, tenaga profesional, dan modal yang cukup besar, guna memperoleh bahan baku, modal bisa dari diri sendiri maupun pijaman dari kreditor. Salah satu penyebab kegagalan perusahaan adalah salah dalam membuat atau mengambil keputusan dalam rangka pengelolaan keuangan sehingga kegiatan perusahaan terganggu.

Di Kabupaten Sorong berdasarkan data dari Dinas Pengolahan Pangan dan Industri tahun 2016 berjumlah 195 jenis usaha. Sedangkan di Distrik Maryat berjumlah 89 unit jenis usaha mulai dari usaha rumah makan, kios, bengkel motor/mobil, pertokoan, penjahit, ternak, meubel dan kue (Dinas Pengolahan Pangan dan Industri Kabupaten Sorong, 2016).

Pia melati adalah salah satu usaha kecil menengah yang bergerak dalam industri pangan di Kabupaten Sorong, tepatnya di Kelurahan Mariyai. Usaha sudah ada sejak tahun 2005 dan sampai sekarang. Usaha ini berjalan cukup baik dan terus mengalami peningkatan produksi karena harga yang cukup murah dan rasanya yang lezat, akan tetapi usaha ini tidak melakukan pembukuan secara teratur sehingga keuntungan perusahaan tidak diketahui secara pasti.

\section{Rumusan Masalah}

Berdasarkan latar belakang yang dikemukakan maka yang menjadi permasalahan dalam penelitian ini seberapa besar keuntungan yang diperoleh oleh Pia Melati?

\section{Tujuan Penelitian}

Tujuan dari penelitian ini adalah menganalisis keuntungan usaha Pia Melati di Kelurahan Mariyai Kabupaten Sorong.

\section{Manfaat Penelitian}

Manfaat dari penelitian ini adalah agar dapat memberikan informasi bagi pihak yang memerlukannya dan menambah wawasan serta pengetahuan mengenai usaha kecil menengah.

\section{METODE PENELITIAN}

\section{Waktu dan Tempat Penelitian}

Penelitian ini dilaksanakan selama 3 bulan, yaitu bulan September 2017 hingga November 2017, mulai dari persiapan hingga penyusunan laporan penelitian ini dilaksanakan pada usaha di Kelurahan Mariyai Kabupaten Sorong.

\section{Metode Pengumpulan Data}

Metode pengumpulan data penelitian yang digunakan dalam penelitian ini adalah studi kasus pada usaha Pia Melati di Kelurahan Mariyai Kabupaten Sorong. Data yang di ambil adalah data primer menggunakan teknik wawancara langsung dengan pemilik usaha. menggunakan daftar pertanyaan yang telah dipersiapkan terlebih dahulu. Data sekunder diperoleh dari Dinas Pengolahan Pangan dan Industri Kabupaten Sorong.

\section{Konsep PengukuranVariabel}

Variabel-variabel yang diukur dalam penelitian ini adalah :

1. Produksi. Jumlah Pia Melati yang dihasilkan dalam sebulan.

2. Harga jual. Harga pia per biji (Rp/biji).

3. Biaya Produksi. Yaitu besarnya biaya yang dikeluarkan setiap kali produksi pia yang terdiri dari :

a) Biaya Tetap :

I. Listrik. Yaitu besar biaya yang dikeluarkan dalam pemakaian listrik dalam proses produksi (Rp/bln).

II. Pajak. Yaitu pajak industri yang didapat dan pajak bumi dan bangunan (Rp/thn).

III. Penyusutan alat. Yaitu nilai penyusutan alat-alat yang digunakan: Alat-alat yang digunakan dalam proses pembuatan pia Nilai penyusutan dihitung dengan menggunakan metode garis lurus atau (straight line method). 
Biaya Penyusutan :

$\frac{\text { Nilai Beli - Nilai Sisa }}{\text { Umur Ekonomis }}$

b) Biaya Variabel

I. Biaya bahan baku. Bahan baku utama yaitu, tepung terigu, kacang hijau, mentega, gula, telur, vanili, gula merah dan minyak goreng $(\mathrm{Rp} / \mathrm{kg})$.

II. Biaya tenaga kerja. Yaitu upah tenaga kerja yang dibayarkan setiap bulan (Rp/bulan).

III. Biaya Tambahan. Biaya pembantu dalam proses industri yaitu berupa toples, air dan gas

4. Penerimaan. Yaitu perkalian antara produksi yang diperoleh dengan harga jual yang dinyatakan dalam rupiah (Rp).

5. Keuntungan. Yaitu nilai yang diperoleh dari total penerimaan dikurangi dengan biaya yang dikeluarkan yang dinyatakan dalam rupiah (Rp).

\section{Metode Analisis Data}

Data yang dikumpulkan dalam penelitian ini kemudian dianalisis dengan menggunakan analisis keuntungan yaitu dengan menghitung selisih antara penerimaan dengan biaya yang digunakan. Data yang dikumpulkan akan disajikan dalam bentuk variabel dan dianalisis secara deskriptif. Dan kemudian akan diukur dengan rumus Analisis Revenue Cost (R/C).

Untuk menghitung total penerimaan menggunakan rumus (Sukirno, 2002).

$$
\mathbf{T R}=\mathbf{Q} \cdot \mathbf{P q}
$$

Dimana :

$\mathrm{TR}=$ Total Penerimaan

$\mathrm{Q}=$ Jumlah produksi yang dijual

$\mathrm{Pq}=$ Harga tiap satuan produk

Untuk menghitung pendapatan menggunakan rumus (Mubyarto, 1994).

$$
\mathbf{I}=\mathbf{T R}-\mathbf{T C}
$$

Dimana :

$$
\begin{aligned}
& \mathrm{I}=\text { Pendapatan (Keuntungan) } \\
& \mathrm{TR}=\text { Total Revenue }(\text { Total Penerimaan }) \\
& \mathrm{TC}=\text { Total Coast }(\text { Total Biaya) }
\end{aligned}
$$

Kemudian untuk mengetahui apakah industri pia ini menguntungkan atau tidak dapat digunakan rumus:

$$
\begin{aligned}
& \mathrm{a}-\mathrm{R} / \mathrm{C} \\
& =(\mathrm{Py} \cdot \mathrm{Y}) /(\mathrm{FC}+\mathrm{VC})
\end{aligned}
$$

Apabila : $\mathrm{R} / \mathrm{C}=1$, berarti industri ini tidak untung atau tidak rugi

$\mathrm{R} / \mathrm{C}<1$, berarti industri ini rugi

$\mathrm{R} / \mathrm{C}>1$, berarti industri untung

Dimana : a $=$ Revenue Cost Ratio

$$
\begin{aligned}
\mathrm{R} & =\text { Revenue } / \text { Penerimaan } \\
\mathrm{C} & =\text { Cost } / \text { Biaya } \\
\mathrm{Py} & =\text { Output Price } / \text { Harga Output } \\
\mathrm{Y} & =\text { Output } \\
\mathrm{FC} & =\text { Fixed Cost } / \text { Biaya Tetap } \\
\mathrm{VC} & =\text { Variable Cost } / \text { Biaya Variabel }
\end{aligned}
$$

\section{HASIL DAN PEMBAHASAN}

\section{Deskripsi Wilayah Penelitian}

Gambaran Umum Kelurahan Mariyai Kecamatan Mariat Kabupaten Sorong Papua Barat.

\section{Keadaan Topografi dan Geografi}

Kelurahan Mariyai adalah bagian wilayah administrasi Kecamatan Mariat dengan batas-batas wilayah sebagai berikut:

a. Sebelah Utara Berbatasan dengan Kelurahan Klasuluk.

b. Sebelah Timur berbatasan dengan Klamalu.

c. Sebelah Selatan berbatasan dengan Klain.

d. Sebelah Barat berbatasan dengan Kampung Arar.

\section{Luas Wilayah Menurut Penggunaan}

Kondisi topografi Kelurahan Mariyai dengan luas wilayah 872 ha.

Penggunaan wilayah terbagi yakni:

a. Kawasan pemukiman penduduk $\pm 90,5 \mathrm{Ha}$.

b. Peruntukan Fasilitas Umum $\pm 10 \mathrm{Ha}$.

c. Lahan Usaha $\mathrm{I} \pm 371 \mathrm{Ha}$.

d. Lahan Usaha II $\pm 400,5$ Ha.

\section{Potensi Sumber Daya Manusia}

Jumlah penduduk Kelurahan Mariyai sampai dengan saat ini adalah sebagai berikut:

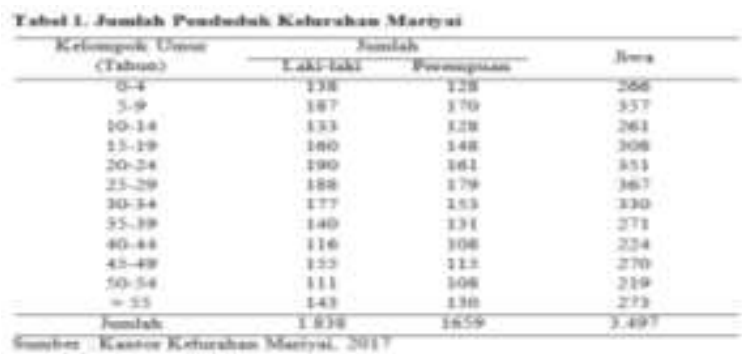




\section{Deskripsi Umum Usaha Pia Melati}

Usaha Pia Melati berdiri sejak tahun 2005, usaha ini letaknya berada di Kelurahan Mariyai Kecamatan Mariat Kabupaten Sorong Papua Barat, awal mula usaha ini hanya coba-coba dengan pengetahuan otodidak Bapak Ali Wijaya melihat peluang bisnis yang baik dari usaha ini, karena dikelurahan Mariyai belum ada usaha sama seperti ini sehingga tidak ada kendala dalam proses produksinya, dan dengan harga yang terjangkau oleh masyarakat umum. Usaha ini bisa dikatakan mempunyai konsumen kelas menengah kebawah, pia Melati ini dijual dengan harga Rp.1.350,- /biji.

Dalam menjalankan usahanya, pemilik ini menjadi pengelola maupun manajer dari Usaha Pia Melati. Usaha ini menggunakan tenaga kerja yang berjumlah 10 orang yang didalamnya sudah termasuk anggota keluarga dari pemilik usaha ini, dan hasil dari produksi ini dipasarkan ke kios-kios dan toko-toko di sekitar Kabupaten dan Kota Sorong.

\section{Produksi}

\section{Produksi, Harga, Penerimaan dan Keuntungan}

Secara umum, istilah "produksi" diartikan sebagai penggunaan atau pemanfaatan sumber daya yang mengubah suatu komoditi menjadi komoditi lainnya yang sama sekali berbeda, baik dalam pengertian apa, dan dimana atau kapan komoditikomoditi itu dilokasikan, maupun dalam pengertian apa yang dapat di kerjakan oleh konsumen terhadap komoditi itu. Istilah produksi berlaku untuk barang maupun jasa, karena istilah "komoditi" memang mengacu pada barang dan jasa. Keduanya samasama dihasilkan dengan mengerahkan modal dan tenaga kerja. Produksi merupakan konsep arus (flow concept), maksudnya adalah produksi merupakan kegiatan yang diukur sebagai tingkat-tingkat output per unit periode/waktu. Sedangkan outputnya sendiri senantiasa diasumsikan konstan kualitasnya (Miller dan Meiners, 2000 dalam Warsana, 2007).

Semua proses produksi dilaksanakan oleh karyawan dalam pengawasan langsung oleh pemilik perusahaan. Selanjutnya proses produksi pembuatan pia secara umum lihat pada gambar di bawah ini :

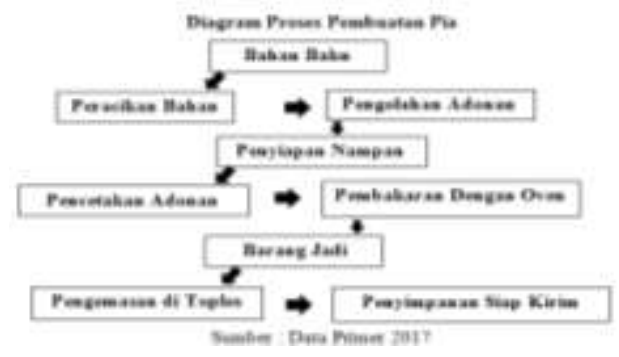

\section{Biaya Produksi Usaha Pia}

Biaya adalah pengeluaran dalam proses produksi yang tidak dapat dihindarkan. Biaya mempunyai peran yang penting dalan pengambilan keputusan setiap usaha. Besarnya biaya yang dikeluarkan untuk memproduksi sesuatu sangat menentukan besar harga dan produk yang dihasilkan.

Biaya produksi yaitu semua biaya yang dikeluarkan dalam pengolahan pia dalam satu kali produks. Komponen biaya terbagi antar biaya tetap dan biaya variabel. Biaya tetap dalam penelitian ini yang dihitung adalah biaya penyusutan peralatan yang digunakan dalam proses pembuatan pia, lahan/tanah, bangunan, pajak yang terdiri atas pajak bumi dan bangunan dan pajak usaha, dan listrik. Sedangkan komponen biaya variabel adalah biaya bahan baku, biaya bahan transportasi dan biaya tenaga kerja dan biaya penolong.

\section{Listrik}

Dalam proses pembuatan pia ini juga menggunakan listrik sehingga biaya yang dikeluarkan dalam proses ini wajib dihitung dan dimasukan dalam biaya, biaya pemakaian listrik usaha ini adalah Rp.750.000/bulan.

2. Pajak

Dalam biaya tetap ini juga yang dihitung, yaitu biaya pajak dimana pajak yang dihitung dalam penelitian ini terdiri atas 2 , yaitu pajak bumi dan bangunan dan pajak usaha sebesar Rp.5.000.000/tahun. Jadi setiap bulan pajak yang dibayarkan sejumlah Rp.400.000.

3. Alat

Penyusutan alat merupakan biaya yang perlu dimasukan kedalam perhitungan biaya tetap. Biaya penyusutan alat yaitu pengurangan nilai yang disebabkan oleh pemakaian alat selama proses berlangsung. Penyusutan yang dihitung adalah umur teknis alat berdasarkan pemakaian alat-alat produksi milik sendiri. Biaya penyusutan dapat dilihat pada Tabel 2.

Tabel 2. Biaya Penyusutan Alat-alat Produksi Pembuatan Pia Dalam Satu Bulan

\begin{tabular}{|c|c|}
\hline $\begin{array}{l}\text { Alat-alat yang Digunakan dalam } \\
\text { Produksi }\end{array}$ & Penyusutan (Rp) \\
\hline Mixer & 16.025 \\
\hline Oven & 6.410 \\
\hline Nampan & 181 \\
\hline Cetakan pia & 38 \\
\hline Total Penyusutan & 22.654 \\
\hline
\end{tabular}

Sumber : Data Primer, 2017

Tabel 2 menunjukkan bahwa penyusutan peralatan dalam produksi pembuatan pia adalah Rp.22.654. Penyusutan alat-alat produksi yang digunakan dipengaruhi oleh umur teknis, harga barang dan nilai sisa. 


\section{Biaya Tetap}

Biaya tetap adalah biaya yang tidak tergantung dari besar kecilnya volume produksi. Dalam penelitian ini biaya tetap yang dihitung adalah pajak bangunan, listrik dan penyusutan alat.

\begin{tabular}{lc}
\multicolumn{2}{c}{ Tabel 3. Biaya Tetap Usaha Pia Melati Dalam Satu Bulan } \\
\hline \multicolumn{1}{c}{ Biaya Tetap } & Biaya (Rp) \\
\hline Penyusutan Alat & 22.654 \\
Pajak bumi dan usaha & 400.000 \\
Listrik & 750.000 \\
\hline \multicolumn{2}{c}{ Total Biaya } \\
\hline Sumber : Data Primer, 2017
\end{tabular}

Tabel 3 menunjukkan bahwa biaya tetap usaha Pia Melati dalam satu bulan, di jumlahkan dengan cara penyusutan alat ditambahkan dengan pajak bumi dan usaha serta listrik maka dapatlah biaya penyusutan dengan jumlah Rp.1.172.654 per bulan.

\section{Biaya Bahan Baku}

Biaya bahan baku dalam proses pembuatan Pia Melati ini merupakan salah satu komponen biaya produksi yang diperhitungkan, biaya bahan baku dalam pembuatan pia ini meliputi Tepung, gula, mentega, minyak goreng, kacang hijau, gula merah, vanili, telur. Dengan rincian sebagai berikut.

Tabel 4. Rata-rata Biaya yang Dikeluarkan dalam Satu Bulan Produksi Pia Melati

\begin{tabular}{lr}
\hline \multicolumn{1}{c}{ Bahan Baku } & Biaya $(\mathrm{Rp})$ \\
\hline Tepung & 13.750 .000 \\
Mentega & 3.125 .000 \\
Gula & 2.100 .000 \\
Telur & 2.800 .000 \\
Vanili & 625.000 \\
Kacang Hijau & 9.350 .000 \\
Minyak Goreng & 3.750 .000 \\
Gula Merah & 3.125 .000 \\
\hline \multicolumn{2}{c}{ Total } \\
\hline
\end{tabular}

Sumber : Data Primer, 2017

Tabel 4 menunjukkan rata-rata biaya yang dikeluarkan dalam satu bulan produksi Pia Melati, yaitu dengan jumlah Rp.38.625.000.

\section{Biaya Tenaga Kerja}

Dalam usaha pembuatan pia ini menggunakan tanaga kerja dari dalam keluarga maupun dari luar keluarga, dan pembayaran gaji baik tenaga kerja luar ataupun dalam adalah sama. Harga yang dibayarkan untuk tenaga kerja yaitu Rp.12.000.000,-/bulan.

\section{Biaya Penolong}

Dalam proses ini biaya penolong juga diperhitungkan, dan biaya tambahan yang dihitung dalam pembuatan pia ini adalah gas, air ukuran 19 liter, toples, ember.
Tabel 5. Biaya Bahan Penolong dalam Satu Bulan

\begin{tabular}{lr}
\hline \multicolumn{1}{c}{ Bahan Penolong } & Biaya (Rp) \\
\hline Air Galon & 175.000 \\
Gas & 3.240 .000 \\
Ember & 150.000 \\
Toples & 2.250 .000 \\
\hline \multicolumn{2}{c}{ Jumlah } \\
\hline Sumber : Data Primer, 2017
\end{tabular}

Sumber : Data Primer, 2017

Tabel 5 menunjukkan biaya bahan penolong dalam satu bulan produksi adalah Rp.5.815.000.

\section{Biaya Variabel}

Biaya variabel adalah biaya yang digunakan dalam satu kali proses produksi dan besar kecilnya biaya dipengaruhi oleh produksi yang diperoleh. Dalam biaya variabel ini yanng dihitung adalah biaya bahan baku, biaya tenaga kerja dan biaya bahan tambahan atau biaya penolong.

Tabel 6. Biaya Variabel Pia Melati dalam Satu Bulan

\begin{tabular}{lc}
\hline \multicolumn{1}{c}{ Biaya-Biaya Produksi } & Total Biaya (Rp) \\
\hline Biaya Bahan Baku & 38.625 .000 \\
Biaya Tenaga Kerja & 12.000 .000 \\
Biaya Penolong & 5.815 .000 \\
\hline \multicolumn{1}{c}{ Total Biaya Variabel } & 56.440 .000 \\
\hline
\end{tabular}

Sumber : Data Primer, 2017

Total biaya usaha Pia Melati dalam satu bulan proses produksi dapat dilihat pada Tabel 7:

Tabel 7. Total Biaya dalam Satu Bulan Proses Pembuatan Pia Melati

\begin{tabular}{cc}
\hline Keterangan & Jumlah (Rp) \\
\hline Biaya Tetap (FC) & 1.172 .654 \\
Biaya Variabel (VC) & 56.440 .000 \\
\hline Total Biaya & 57.612 .654 \\
\hline Sumber: Data Primer, 2017 &
\end{tabular}

\section{Harga}

Harga adalah satuan moneter atau ukuran lainnya termasuk barang dan jasa lainnya yang ditukarkan agar memperoleh hak kepimilikan atau pengguna suatu barang dan jasa. Berdasarkan beberapa pengertian di atas maka dapat disimpulkan bahwa harga merupakan keseluruhan nilai suatu barang maupun jasa yang diberikan dalam bentuk uang. Selain itu Harga adalah segala sesuatu atau nilai yang ditetapkan (Tjiptono, 2005). /biji.

Harga untuk pia Melati, yaitu Rp.1.350,-

\section{Penerimaan}

Penerimaan adalah jumlah produksi dikali dengan harga jual yang berlaku (Wilson, 2007 dalam Sumampouw, 2015). Dalam kegiatan usaha, perusahaan selalu meningkatkan produksi dengan harapan bahwa pendapatan yang diterima akan naik 
sejalan dengan bertambahnya produksi yang dihasilkan. Penerimaan berkaitan erat dengan volume produksi dan harga jual, oleh karena itu penerimaan merupakan hasil perkalian antara harga jual yang berlaku dalam produksi.

Tabel 8. Total Penerimaan dari Proses Produksi Pia Melati di Kelurahan Mariyai Kabupaten Sorong

\begin{tabular}{|c|c|}
\hline Keterangan & Jumlah (Rp) \\
\hline Produksi & 2.300 \\
\hline Harga & 1.350 \\
\hline Total penerimaan & 77.625 .000 \\
\hline
\end{tabular}

Sumber : Data Primer, 2017

Jadi penerimaan usaha pia Melati ini dalam satu bulan produksi adalah sebesar Rp.77.625.000,--

\section{Keuntungan}

Keuntungan yang diperoleh sangat tergantung dari jumlah penerimaan yang diterima dikurangi dengan biaya yang dikeluarkan, besarnya penerimaan yang didapat merupakan hasil perkalian antara harga jual produk dengan jumlah produk yang dihasilkan shingga semakin tinggi produksi dengan biaya kecil dan harga akan mempengaruhi keuntungan. Keuntungan usaha Pia Melati dapat dilihat pada Tabel 9.

Tabel 9. Total Keuntungan Usaha Pia Melati di Kelurahan Mariyai Kabupaten Sorong dalam Satu Bulan Produksi

\begin{tabular}{lc}
\hline \multicolumn{1}{c}{ Keterangan } & Jumlah $(\mathrm{Rp})$ \\
\hline Total Penerimaan & 77.625 .000 \\
Total Biaya & 57.612 .654 \\
\hline \multicolumn{1}{c}{ Keuntungan $(\mathrm{Rp})$} & 20.012 .346 \\
\hline
\end{tabular}

Sumber : Data Primer, 2017

Tabel 9 menunjukkan bahwa keuntungan yang diterima adalah sebesar Rp.20.012.346,-. Dari Tabel 9 dapat dilihat bahwa usaha ini dapat menambah pendapatan dalam pemenuhan kebutuhan hidup.

\section{Analisis Revenue Cost Ratio}

Tingkat keuntungan ekonomi dapat diketahui dengan menggunakan Analisis Revenue Cost Ratio (R/C ratio) adalah perbandingan antara penerimaan dan biaya, ratio yang menjadi parameternya adalah nilai $\mathrm{R} / \mathrm{C}=1$ berarti usaha tidak untung dan tidak rugi, nilai $\mathrm{R} / \mathrm{C}<1$ berarti usaha rugi, nilai $\mathrm{R} / \mathrm{C}>1$ berarti usaha untung. Nilai R/C Usaha Pia Melati di Kelurahan Mariyai Kabupaten Sorong dapat dilihat pada Tabel 10.

Tabel 10. Usaha Pia Melati di Kelurahan Mariyai Kabupaten

\begin{tabular}{cc} 
Sorong & \\
\hline Keterangan & Jumlah $(\mathrm{Rp})$ \\
\hline Total Penerimaan & 77.625 .000 \\
Total Biaya Produksi & 57.162 .654 \\
\hline R/C Ratio & 1,35 \\
\hline
\end{tabular}

Tabel 10 menunjukkan bahwa usaha ini memiliki Ratio/Cost Ratio adalah 1,35 yang dimana menunjukkan bahwa usaha ini tidak rugi.

\section{KESIMPULAN DAN SARAN}

\section{Kesimpulan}

Dalam penelitian ini dapat disimpulkan bahwa usaha Pia Melati di Kelurahan Mariyai Kabupaten Sorong ini menguntungkan. Usaha pia melati ini mengeluarkan biaya dalam sebulan produksi adalah Rp.57.162.654 dengan penerimaan Rp.77.625.000 dan mendapatkan keuntungan Rp.20.012.346 dalam sebulan produksi. Dan jika menggunakan $\mathrm{R} / \mathrm{C}$ cost revenue 1,35 yang berarti usaha ini menguntungkan dan dapat dipertahankan.

\section{Saran}

Berkaitan dengan hasil penelitian ini, maka pengembangan industri dan proses pembuatan pia harus lebih diefektifkan agar bisa mendapatkan keuntungan yang maksimal.

\section{DAFTAR PUSTAKA}

Mubyarto. 1994. Pengantar Ekonomi Pertanian. LP3ES, Jakarta.

Sukirno, S. 2002. Pengantar Teori Mikroekonomi. Raja Grafindo Persada, Jakarta.

Sumampouw N. N, O. Esry Laoh, dan Lyndon R. J. Pagemanan. 2015. Analisis Tingkat Keuntungan Usaha Rumah Tangga Kue Lumpia di Kelurahan Bumi Nyiur Kecamatan Wanea. Jurnal Agrososioekonomi Volume 11 No 3A, November 2015:125-142. Fakultas Pertanian Unsrat. Ejournal Www. Unsrat. ac. id. Diakses tanggal 1 Februari 2018.

Tjiptono. 2005. "Pengertian Harga". Diakses tanggal 6 Februari 2018 http:// pengertian harga. blogspot.com /2016 /03 /pengertian-hargamenurut-para-ahli. html.

Warsana. 2007. Analisis Efisiensi dan Keuntungan Usaha Tani Jagung (Studi di Kecamatan Randublatung Kabupaten Blora). Tesis Universitas Diponegoro Semarang. StarPdf. com. Diakses tanggal 16 Januari 2018.

2016. Dinas Pengolahan Pangan dan Industri. Kabupaten Sorong. Papua Barat. 